Article

\title{
The Impact of Subsidy Programs for Solar Thermal Applications: A Case Study for a Remote Island
}

\author{
Wei-Min Lin ${ }^{1}$, Keh-Chin Chang ${ }^{2}$ and Kung-Ming Chung ${ }^{2, *}$ \\ 1 Department of Accounting Information, Tainan University of Technology, 529 Jhongjheng Rd., Yongkang, \\ Tainan 710, Taiwan; t20043@mail.tut.edu.tw \\ 2 Energy Research Center, National Cheng Kung University, 2500 Sec. 1, Chung-Cheng S. Rd, Guiren, \\ Tainan 711, Taiwan; kcchang@mail.ncku.edu.tw \\ * Correspondence: kmchung@mail.ncku.edu.tw; Tel.: +886-6239-2811; Fax: +886-6239-1915
}

Received: 18 September 2019; Accepted: 16 October 2019; Published: 17 October 2019

\begin{abstract}
Government intervention in the form of financial incentives is crucial for translating customer choice into a larger market share for solar thermal applications. The lengthy subsidy programs for solar water heaters in Taiwan have expanded the local market. On a remote island (Kinmen County), the area of solar collectors that are installed per 1000 inhabitants is 192.9 square meters. This study investigates a market-driven mechanism in terms of disposable income, household structure, building type and financial viability. The dual subsidy programs appear to have distorted the local market. The cumulative energy savings for solar water heaters that are installed is misleading because the systems are over-designed and there is a high replacement rate (or shorter service period).
\end{abstract}

Keywords: subsidy; solar thermal; renewable energy

\section{Introduction}

Greenhouse gas emissions and global climate change are of concern around the world. The adoption of renewable energy sources is increasing rapidly, primarily due to protocol agreements and legislative requirements. Government intervention in the form of financial incentives has a profound effect on market expansion [1]. In 2018, the annual respective energy yields worldwide from wind power, solar photovoltaic power and solar thermal heat were $1470 \mathrm{TWh}, 640 \mathrm{TWh}$ and 396 TWh [2]. Solar thermal is a mature technology [3-7]. Solar water heaters (SWHs) consist of solar collectors (flat plate or evacuated tubes), connecting pipes, a water storage tank, and auxiliary heating elements, in which the tank is installed either above solar collectors (thermosyphon systems) or at a lower level (forced circulation). In the domestic sector and in some industries with relatively low energy consumption (food, agro, textiles, chemical, or beverage industries), SWHs (no sun tracking) can be used to produce hot water at $40-80^{\circ} \mathrm{C}$ [8]. Solar thermal technology can also be used for industrial heat processes with the required temperatures of $60-260^{\circ} \mathrm{C}$. The processing temperature, the collectors and the load profile are the most important factors for system performance [9]. Powel et al. [10] reviewed concentrated solar power (CSP) hybridization strategies with other energy resources. A high solar fraction of $70 \%$ can be achieved for a tower-driven CSP hybridized with a combined cycle power plant [11]. Improved environmental benefits can also be obtained by hybridizing the solar power with natural gas at a plant-level [12].

Financial incentive programs (direct subsidies, performance-based subsidy, tax credits or tax deductions) have been used as policy tools by some governments [13-18]. In terms of the installation rate, most subsidy programs have a positive effect on the dissemination of SWHs. However, some programs are disappointing [19]. Mauthner et al. [2] noted that the total area of solar collectors installed (SWHs in operation) was 686 million $\mathrm{m}^{2}$ (or $480 \mathrm{GWth}$ ) in 68 countries (4.9 billion people; $66 \%$ of the 
world population) by the end of 2018. This means that the area of solar collectors that are installed, $A_{s c}$, per 1000 inhabitants, $A_{s c}{ }^{*}$, is approximately $140 \mathrm{~m}^{2}$. In other words, there is $98 \mathrm{~kW}_{\text {th }}$ per 1000 inhabitants when a factor of $0.7 \mathrm{~kW}$ th $/ \mathrm{m}^{2}$ is used to derive the nominal capacity from $A_{s c}$.

In Taiwan, the ratio of imported energy to total energy supply is more than $98 \%$. The "Energy Administration Act" promotes energy security, a green economy, environmental sustainability and social equity. The target of a nuclear-free homeland is also scheduled for completion in 2025 [20]. The installation of renewable energy sources is a critical issue. For solar thermal applications, the amount of solar radiation ranges from 1200 to $1700 \mathrm{kWh} / \mathrm{m}^{2} /$ year. Purchase-based subsidy programs have been initiated by the government of Taiwan (1986-1991, 2000-2018) and some local governments (Kinmen County, Penghu County, Kaohsiung City, etc.) [21]. The payback period (6 to 15 years) depends on the region and the type of water heater that is being replaced [22]. The statistical data also shows that financial incentives are effective in the initial stage of each subsidy program. The potential market for SWHs depends on the type of building, disposable income, household structure and climatic conditions $[23,24]$. Cottages or duplex houses are more likely to have a SWH on the roof and there is limited installation of SWHs in metropolitan areas. Households with a greater disposable income are more willing to purchase SWHs. The value of $A_{s c}$ for SWHs in the domestic sector depends on the household structure of end users. Strong wind loads during typhoons are another major concern [25-28].

In Taiwan, the value for $A_{S C}{ }^{*}$ ranges from 2.33 in Taipei City (the lowest) to 192.9 in Kinmen County (the highest) [21]. To formulate a new policy for the dissemination of SWHs, it is important to account for different factors. This study comprehensively analyzes the installation of SWHs in Kinmen and the role of energy cooperatives. The data from this study is relevant to authorities in other countries that wish to promote the use of SWHs.

\section{Methodology}

In the period 2000-2018, an operation unit was authorized by the Bureau of Energy of the Ministry of Economic Affairs (BEMOEA). The Energy Research Center at National Cheng Kung University (ERC/NCKU) took charge of the subsidy program for SWHs. All products (solar collectors and SWHs), installers/dealers, and manufacturers must possess a certification or license issued by the BEMOEA for them to be eligible for the subsidy programs. A comprehensive database was compiled. An SWH user is required to fill in an application form, which includes household composition, housing status and specifications/price of product. The information about the system is then statistically analyzed to generate the regional distribution of SWHs. More than 72,000 interviews ( $20 \%$ of end users) were also conducted to record system performance, technical problems and post-installation service. Please note that the ERC/NCKU documents all the details for SWHs installed in Kinmen County (2000-2018) for the present study. To determine the dominant factors that affect the dissemination of SWHs, data from official sources [29] was also used, including the household structure, the family's disposable income, and the type of building.

\section{SWHs in Taiwan and Kinmen County}

Taiwan in situated between $22^{\circ}$ and $25^{\circ}$ North. The average daily horizontal global solar insolation in Taiwan ranges from $3.25 \mathrm{kWh} / \mathrm{m}^{2}$ to $4.64 \mathrm{kWh} / \mathrm{m}^{2}$. In Kinmen County ( $24^{\circ} 24^{\prime}$ North), the value is $4.12 \mathrm{kWh} / \mathrm{m}^{2}$, which is calculated using the data shown in Figure 1. This area is suited to the installation of solar thermal devices. The SWH market and the dominant factors are presented in the following. 


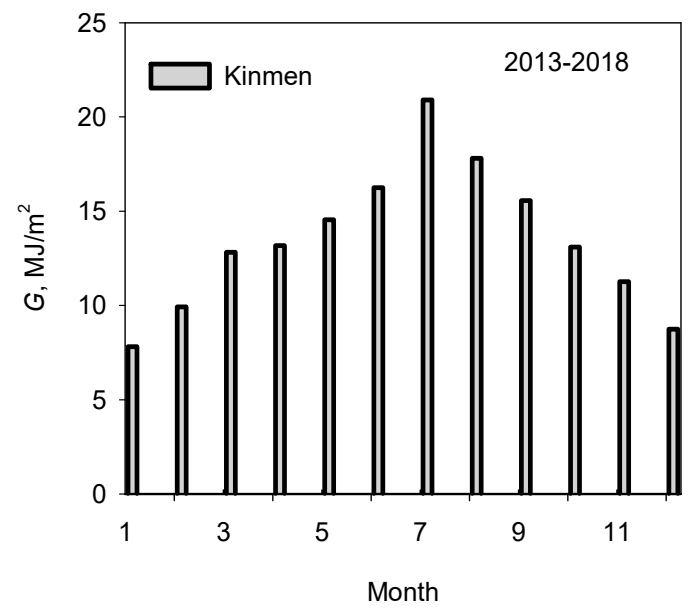

Figure 1. Average monthly global horizontal solar radiation in Kinmen County for solar thermal application.

\subsection{SWH Market}

The BEMOEA initiated the first purchase-based subsidy program in 1986. The SWH industry expanded quickly and the annual area of solar collectors installed, $\Sigma A_{s c}$, was approximately $60,000 \mathrm{~m}^{2}$ in 1991. To promote the application of solar thermal energy, the BEMOEA announced the second subsidy program in 2000. As shown in Table 1, a direct subsidy of $1500 \mathrm{NT} \$ / \mathrm{m}^{2}$ for glazed flat-plate solar collectors or evacuated-tube solar collectors was applied from 2000 to 2008 . The amount of this subsidy was doubled on remote islands, such as Kinmen County. The ratio of subsidy to the initial capital cost (RSC) ranges from $18.3 \%$ to $21.3 \%$ [30]. A revised subsidy program was launched in 2009 and there was a $50 \%$ increase $\left(2250 \mathrm{NT} \$ / \mathrm{m}^{2}\right)$ in the subsidy. The program was terminated in 2017 and the subsidy was $2000 \mathrm{NT} \$ / \mathrm{m}^{2}$ in 2016 and $1750 \mathrm{NT} \$ / \mathrm{m}^{2}$ in 2017. For remote islands, the program was extended to 2018 with a subsidy of $3000 \mathrm{NT} \$ / \mathrm{m}^{2}$. The government of Kinmen County also offered financial incentives. The amount of the subsidy was $3000 \mathrm{NT} \$ / \mathrm{m}^{2}$ in $2008(\mathrm{RSC} \approx 51 \%)$ and $4500 \mathrm{NT} \$ / \mathrm{m}^{2}$ in 2009 (RSC $\approx 89 \%$ ). An upper limit was enforced in April 2010 to limit the subsidy for a domestic SWH to a value for $A_{s c}$ of $6 \mathrm{~m}^{2}$. In 2018, the sum of subsidies that were offered by the BEMOEA and the government of Kinmen County was 8000 NT\$ $/ \mathrm{m}^{2}$.

Table 1. Purchase-based subsidy programs in Taiwan and Kinmen (2000-2018).

\begin{tabular}{ccc}
\hline Funding Agency & Period & Collector-Area-Based Subsidies \\
\hline BEMOEA & $2000.07-2008.12$ & $1500 \mathrm{NTD} / \mathrm{m}^{2} *$ \\
& $2009.01-2015.12$ & $2250 \mathrm{NTD} / \mathrm{m}^{2}$ \\
& $2016.01-2016.12$ & $2000 \mathrm{NTD} / \mathrm{m}^{2}$ \\
& $2017.01-2017.12$ & $1750 \mathrm{NTD} / \mathrm{m}^{2}$ \\
& $2018.01-2018.12$ & $3000 \mathrm{NTD} / \mathrm{m}^{2}$ for remote islands \\
& $2008.03-2008.12$ & $3000 \mathrm{NTD} / \mathrm{m}^{2}$ \\
Government of Kinmen County & $4500 \mathrm{NTD} / \mathrm{m}^{2}$ \\
& $2009.01-2017.12$ & Subsidizing up to $A_{s c}=6 \mathrm{~m}^{2}$ after 1 April 2010 \\
& $2018.01-2018.12$ & $5000 \mathrm{NTD} / \mathrm{m}^{2}$ \\
\hline & $* 1 \mathrm{USD} \approx 31 \mathrm{NTD}$ &
\end{tabular}

The historical data for Taiwan for $\Sigma A_{s c}$ from 1982 to 2018 is shown in Figure 2. The value of $\Sigma A_{s c}$ is less than $10,000 \mathrm{~m}^{2}$ from 1982 to 1985 , but is approximately $60,000 \mathrm{~m}^{2}$ at the end of the first subsidy program (1991). The second subsidy program also results in a substantial increase in the use of domestic SWHs to $100,000 \mathrm{~m}^{2}$ in 2004. The peak value of $136,000 \mathrm{~m}^{2}$ in 2010 corresponds to a $50 \%$ increase for the subsidy, following a decline in the SWH market. In 2016 and 2017, the value of $\Sigma A_{s c}$ is less than $100,000 \mathrm{~m}^{2}$ because there is a reduction in the subsidy. At the end of the subsidy program, there is a significant decrease in the value of $\Sigma A_{s c}$ to approximately $36,000 \mathrm{~m}^{2}$. The effectiveness of the 
long-term subsidy program is questionable, as is the sustainability of solar thermal applications and SWH industry. For Kinmen County, the historical data (2001-2018) is shown in Figure 3. The market size was very limited between 2001 and $2007\left(\Sigma A_{s c}=7.6-219.8 \mathrm{~m}^{2}\right.$ or less than 30 SWHs installed per annum). The local subsidy program led to a sustainable increase in SWH sales $\left(\Sigma A_{s c}=749 \mathrm{~m}^{2}\right.$ or 114 SWHs installed in 2008) and there is a peak value for $\Sigma A_{s c}$ in $2010\left(=6465 \mathrm{~m}^{2}\right.$ or 901 SWHs installed). From 2011 to 2018, the SWH market in Kinmen County is similar to that for Taiwan as a whole.

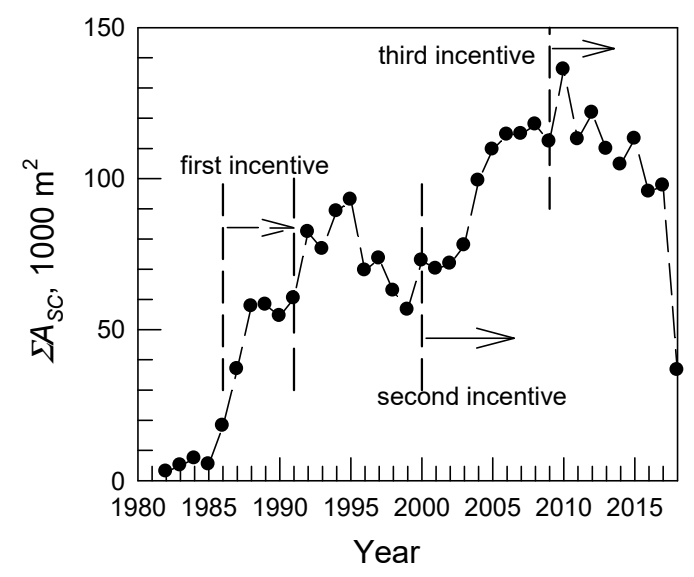

Figure 2. The annual area of solar collectors installed $\Sigma A_{s c}$ for Taiwan (1982-2018).

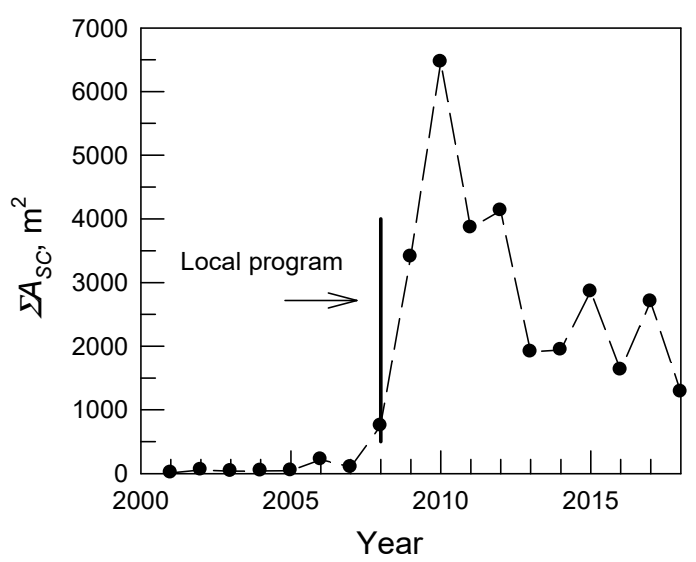

(a)

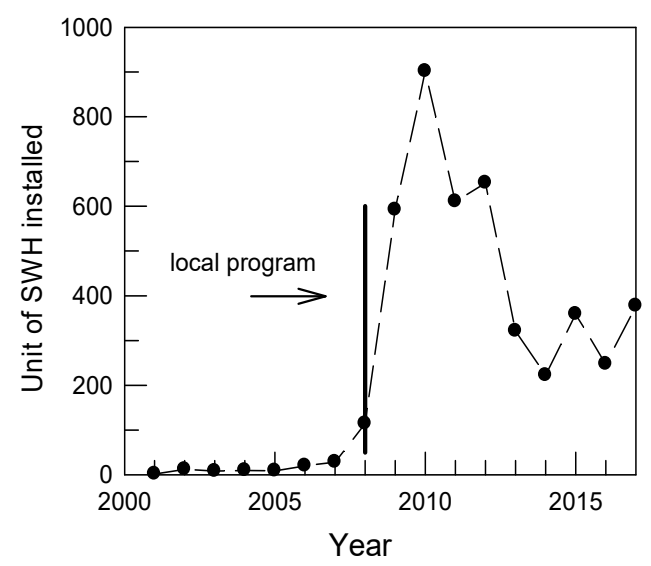

(b)

Figure 3. SWHs installed for Kinmen (2001-2018). (a) Annual area of solar collectors installed; (b) Unit of SWHs installed. 


\subsection{Market-Driven Mechanism}

Chung et al. $[23,24]$ showed that the dissemination for SWHs depends on the type of building, disposable income, household structure and climatic conditions. The style of building with a SWH installed is shown in Figure 4. On the Taiwanese mainland (2001-2018), 2-5-storey houses have the highest market share $(62.7 \%)$. This is also true for Kinmen County. The market share for flat housing in Kinmen County $(29.6 \%)$ is much greater than that for the Taiwanese mainland (10.6\%). This is because the flat housing units account for $34.6 \%$ of all buildings in Kinmen County, and that figure is $11.3 \%$ for the Taiwanese mainland [29].

Economic viability is a dominant factor for the use of SWHs. The motivation to install a SWH depends on a family's disposable income and other investment priorities. The historical data for a family's disposable income is shown in Figure 5. In 2001-2007 and 2010-2017, the annual increase for the Taiwanese mainland is less than $3 \%$. The decrease in 2008 is due to the global financial crisis. In Kinmen County, there is staggered data, and the figure is up to $18 \%$ (2006) less than that for the Taiwanese mainland, but not for 2013. The initial capital cost for SWHs is also related to the composition of families. The guideline for system design is an area of solar collectors of $1 \mathrm{~m}^{2}$ per person. Chang et al. [30] noted that the unit price of a larger SWH $\left(A_{s c},=5-10 \mathrm{~m}^{2}\right)$ is only about half that of a smaller SWH $\left(A_{s c}<3 \mathrm{~m}^{2}\right)$. Figure 6 shows the household structure for SWH users in the period of 2001-2018. There is a continuous decrease for the Taiwanese mainland from 3.29 to 2.70 persons/household. The opposite is true for Kinmen County. In 2004, a 34\% increase in the number of households results in a large decrease in the number of persons per household $(=2.48)$ because of a local household-based financial program. For 2014-2018, the figure is approximately 3.44. Census data [29] shows that regular residents in Kinmen County account for less than $60 \%$ of the population, so there are 2.06 persons per household.

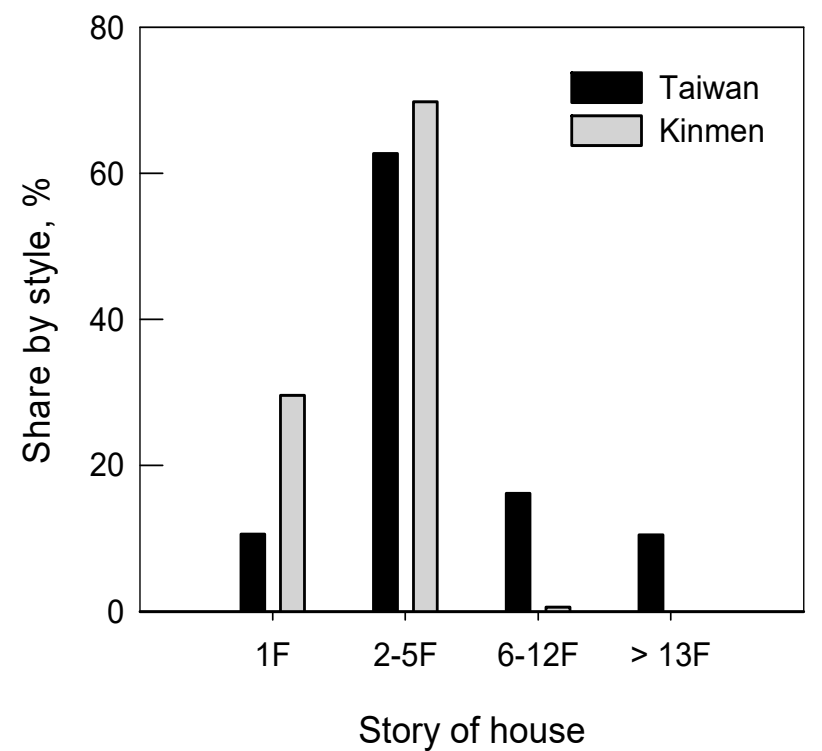

Figure 4. Style of building with a SWH installed (2001-2018) in Taiwan and Kinmen County. 


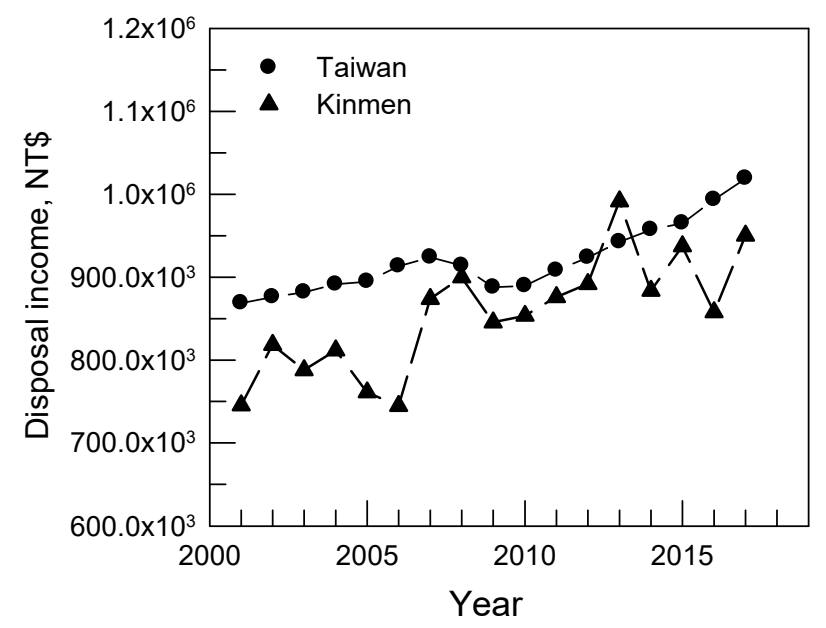

Figure 5. Average disposable income per household in Taiwan and Kinmen County.

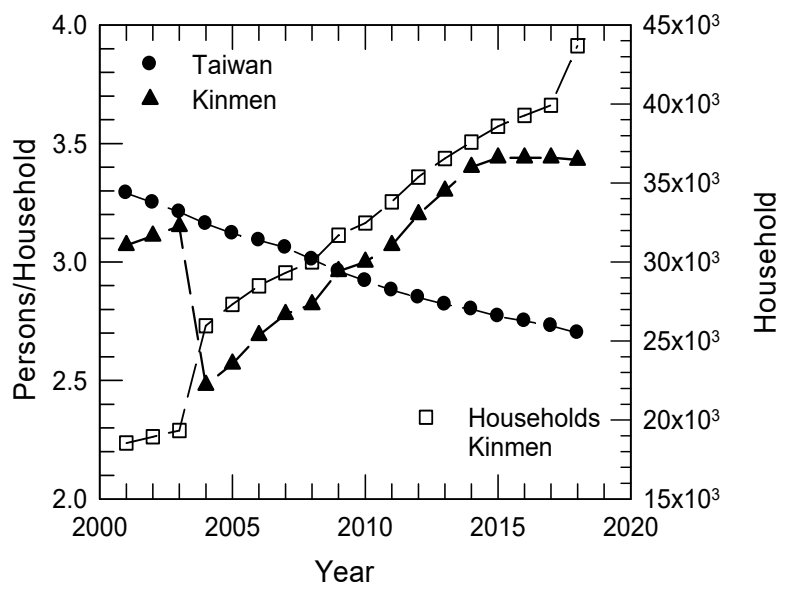

Figure 6. Household structure for SWH users in Taiwan and Kinmen County.

\section{Results and Discussion}

As shown in Figure 3, the local subsidy program by the government of Kinmen boosts the SWH market, and Kinmen County has the highest value of $A_{S C}$ * in Taiwan. The market share, in terms of the scale of SWHs, is shown in Figure 7. On the Taiwanese mainland, an $A_{s c} / \mathrm{SWH}$ value of 3-5 and 5-10 respectively corresponds to $44.1 \%$ and $41.5 \%$. The market share for one- or two-person households $\left(A_{s c} / \mathrm{SWH}<3\right)$ is $12.5 \%$. The household structure in Kinmen County and on the Taiwanese mainland shows an opposite trend for 2004-2018. An $A_{s c} / S W H$ value of 5-10 (81.2\%) dominates the market in Kinmen County.

The historical data for 2001-2018 for $A_{s c} / S W H$ is shown in Figure 8a. There is slight variation in the value of $A_{s c} / \mathrm{SWH}$ ( $\left.=4.77-5.33\right)$ for the Taiwanese mainland. In Kinmen County, the limited number of SWHs installed for 2001-2008 and the value of $A_{s c} / \mathrm{SWH}$ ranges from 3.52 to 4.80 . The highest value for $A_{s c} / S W H(=6.38)$ in 2010 is due to a high ratio of subsidy to initial capital cost and the over-design of systems [30]. For 2011-2018, the figure is 5.72-6.02, which is reasonable in comparison with that for the Taiwanese mainland, in terms of the household structure of SWH users.

The data for $A_{s c}$ per person, $A_{s c} /$ person, is plotted in Figure $8 \mathrm{~b}$. The value for $A_{s c} /$ person for the Taiwanese mainland ranges from 1.56 (2007) to 1.87 (2016). In Kinmen County, there was large variation for 2001-2011. The value for $A_{s c} /$ person increased significantly from 1.27 to 2.13 in 2007-2010. As previously mentioned, this is due to the dual subsidy programs by the BEMOEA and the government of Kinmen County. Note that an opposite trend, i.e., a decrease in the value of $A_{s c} /$ person $(=1.80-1.67)$, was observed for 2012-2018. However, the regular residents account for less than $60 \%$ of 
the population [29], so the average value for $A_{s c}$ /person in Kinmen County is approximately 2.88 for 2012-2018, which is considerably greater than the figure for the Taiwanese mainland (=1.84 in 2017).

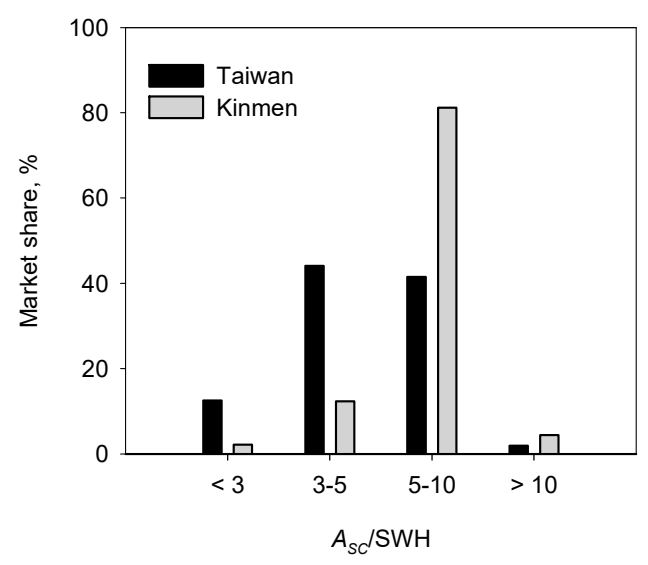

Figure 7. Market share in terms of scale of SWHs in Taiwan and Kinmen County.

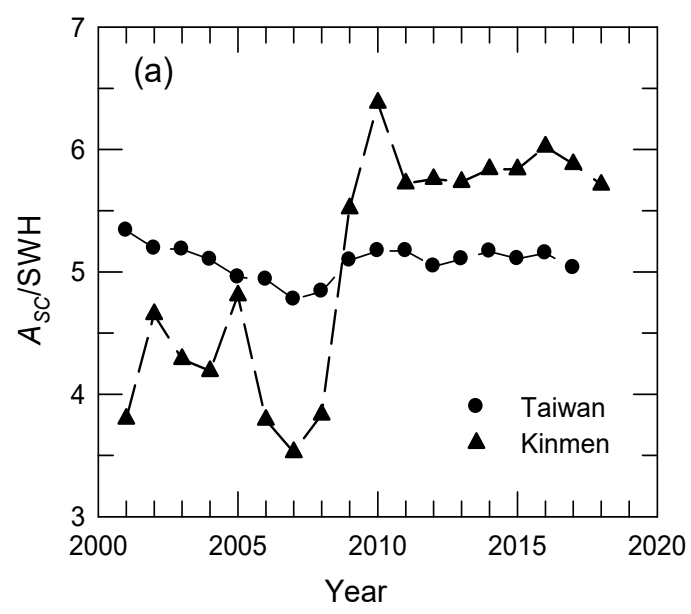

(a)

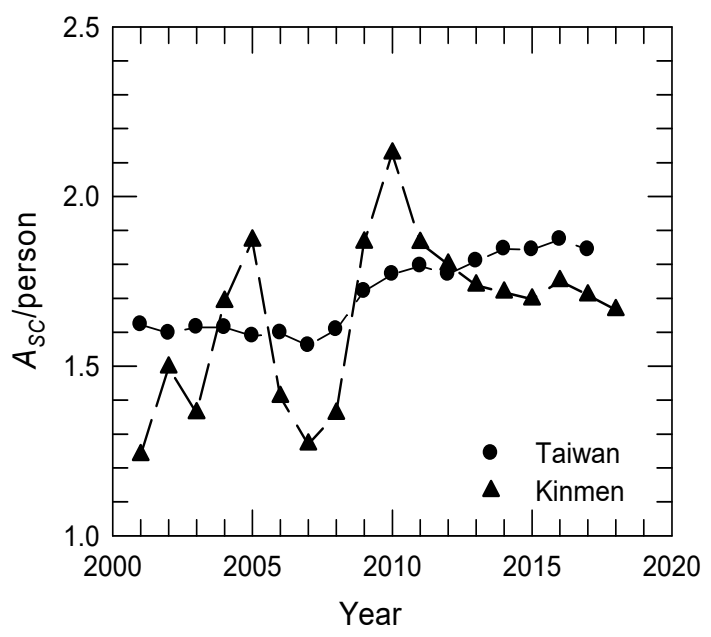

(b)

Figure 8. Scale of SWHs (2001-2018) in Taiwan and Kinmen County. (a) Area of solar collectors per SWH; (b) Area of solar collectors per person. 
The financial viability of SWHs depends on the initial capital cost. The average unit price, which is related to the scale of sales and $A_{s c}$, is shown in Figure 9. For the Taiwanese mainland, the initial reduction in the value for 2001-2004 corresponds to an increase in sales. An increase in the price of raw materials results in a 39\% increase for 2006-2008. There is a slight variation for 2009-2017, for which period the unit price equals 10,550 $\pm 350 \mathrm{NT} \$ / \mathrm{m}^{2}$. From 2001 to 2007 , a substantial variation for Kinmen County is related to the limited numbers of SWHs that are installed or the scale of sales. The unit price equals $11,500 \pm 280 \mathrm{NT} \$ / \mathrm{m}^{2}$ for 2008-2017, but not for 2010, which has a peak value for $\Sigma A_{s c}$. Since all manufacturers of SWHs are located on the Taiwanese mainland, the $9 \%$ increase is due to transportation/shipping costs. Note that the subsidy by the BEMOEA is double in Kinmen County, and the local program also has a significant effect on market expansion. This explains the peak value of $A_{S C}{ }^{*}(=192.9)$ for Kinmen County. Lin et al. [31] showed that financial viability depends on the proper sizing of a system. An over-designed system (greater value of $A_{s c} /$ person in Kinmen County) does not result in increased cumulative energy savings during the lifespan of a system, but there is a longer payback period due to the greater initial capital cost.

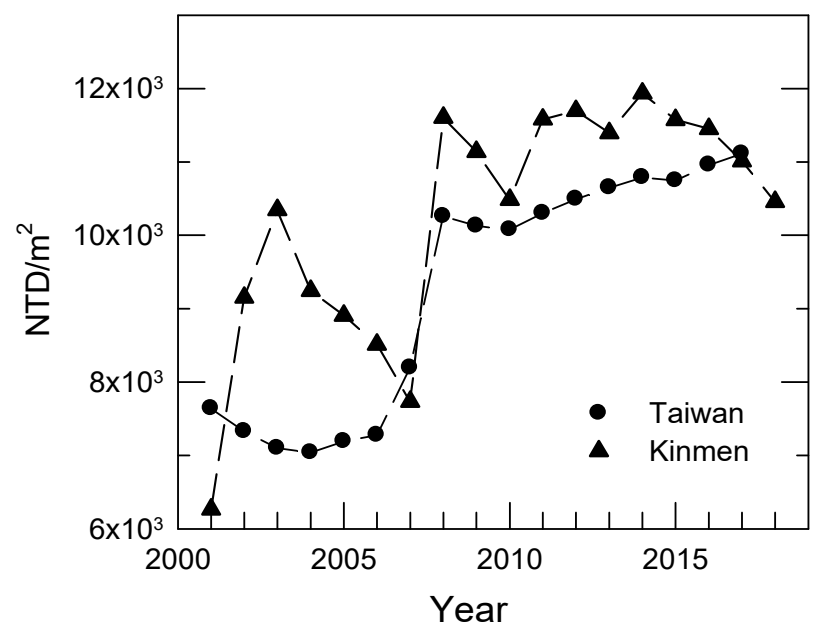

Figure 9. Initial capital cost in terms of the area of solar collectors in Taiwan and Kinmen County.

The marketing of SWHs cannot be solely based on word of mouth and previous experience with the products. Technical guarantees (actual performance) and after-sale service also have a significant effect on the dissemination of SWHs. Wierling et al. [32] noted that energy cooperatives are important actors in the field of renewable energies. For the national subsidy program for 2000-2018, installers and technicians of SWHs had to gain certification. The historical data for certified installers, CIs, is shown in Figure 10. For the Taiwanese mainland, there were fewer than 100 CIs by 2005. The revised subsidy program in 2009, as shown in Table 1, resulted in a significant increase in the number of CIs (more than 300 in 2014). For the period 2001-2007, only one CI was in operation, and 89 SWHs were installed in Kinmen County. When the local subsidy program was introduced, $901 \mathrm{SWHs}$ were installed in 2010, and there were 14 CIs. This proves that the number of CIs is an important actor in the adoption of SWHs.

The historical data shows that the local subsidy program had a significant effect in terms of market expansion. However, the cumulative energy savings for a SWH depend on the service period of the SWH. Chang et al. [21] showed that most Taiwanese SWHs have a service period of 15 years. The replacement statistics for SWHs in Kinmen County is shown in Figure 11. 779 of the 4659 SWHs that were installed (16.7\%) in 2001-2018 were replaced within 15 years. The peak values correspond to 5 (136 SWHs) and 6 (154 SWHs) years of use. Although tap water causes slightly elevated levels of scaling and there is a relatively higher risk of corrosion for underground water [33], the 16.7\% replacement rate is unusual. The regulations for Kinmen County stipulate that the end users can apply to replace systems that have been in operation for more than 5 years. As shown in Table 1, the dual 
subsidies range from $7000 \mathrm{NT} \$ / \mathrm{m}^{2}$ to $9000 \mathrm{NT} \$ / \mathrm{m}^{2}$ for $2008-2018$. When solar collectors only are replaced (not including storage tanks, controllers and supporting structure), the end users replace the old system at the least cost. Therefore, the energy savings based on the cumulative area of solar collectors for Kinmen County are misleading. The effectiveness of the dual subsidy program in real energy savings should be carefully interpreted.

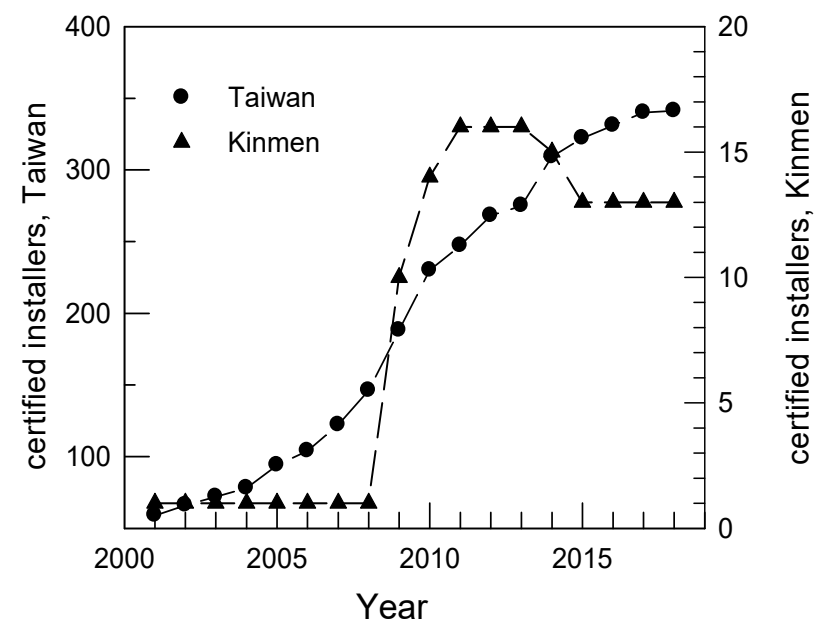

Figure 10. Historical data for certified installers in Taiwan and Kinmen County.

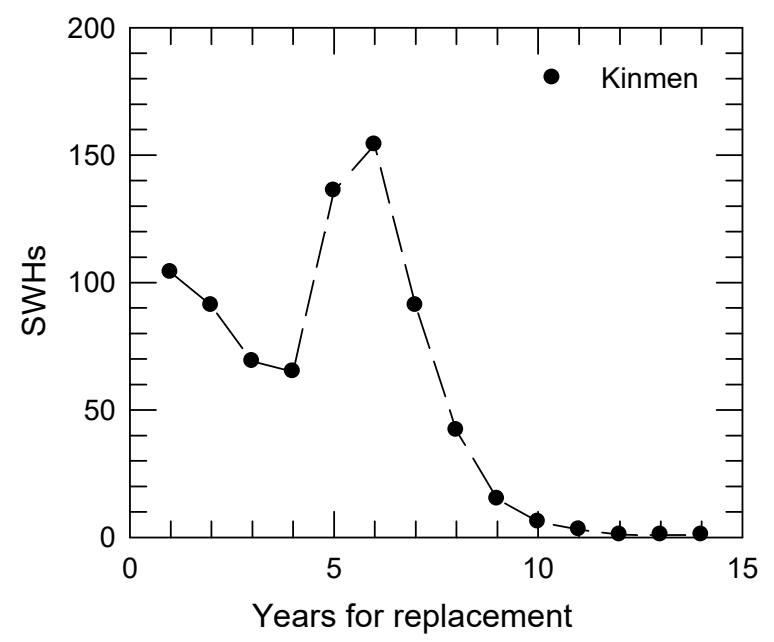

Figure 11. System replacement in Kinmen County.

\section{Conclusions}

The local market for SWHs depends on the type of building, disposable income, household structure and climatic conditions. The dual subsidy programs by the BEMOEA and local government have had a significant effect on the dissemination of SWHs in Kinmen County. There is a sustainable increase in SWH sales. The value for the area of solar collectors that are installed per 1000 inhabitants is 192.9, which is the highest in Taiwan.

The guideline for system design is an area of solar collectors of $1 \mathrm{~m}^{2}$ per person. The average value in Kinmen County for 2012-2018 was 2.88 (over-designed systems) and an $A_{s c} / \mathrm{SWH}$ value of 5-10 $(81.2 \%)$ dominates the local market. This corresponds to a high ratio of subsidy to the initial capital cost. However, energy savings depend on the proper sizing of a system (or hot water consumption pattern). An over-designed SWH does not result in an increase in cumulative energy savings during the lifespan of a system. For system replacement, most Taiwanese SWHs have an expected service period of 15 years. In Kinmen County, 16.7\% SWHs were replaced within 15 years, with the peak 
values corresponding to 5 or 6 years of use. Since the cumulative energy savings for a SWH depend on the service period of the SWH, the energy savings based on the cumulative area of solar collectors for Kinmen County are misleading. The effect of dual subsidy programs on the sustainability for solar thermal applications requires more carefully interpretation. The historical data also shows that the area of solar collectors installed per annum is associated with the number of certified installers. This indicates that energy cooperatives are an important actor for the adoption of SWHs.

Author Contributions: Conceptualization, K.-C.C. and K.-M.C.; methodology, W.-M.L.; formal analysis, W.-M.L. and K.-M.C.; data curation, W.-M.L. and K.-M.C.; writing-original draft preparation, W.-M.L. and K.-M.C.; writing-review and editing, K.-C.C.; project administration, K.-C.C.; funding acquisition, K.-C.C.

Funding: This research received no external funding.

Acknowledgments: This work was supported by the Government of Kinmen County, Taiwan.

Conflicts of Interest: The authors declare no conflict of interest.

\section{Nomenclature}

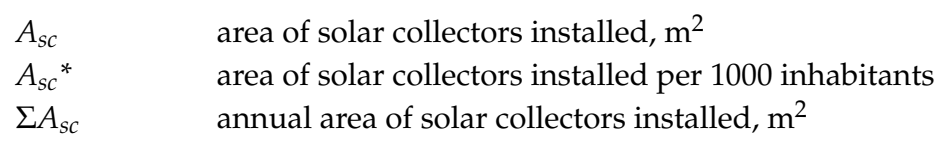

\section{Abbreviations}

BEMOEA Bureau of Energy, Ministry of Economic Affairs

CIs certified installers

RSC ratio of subsidy to initial capital cost

SWHs solar water heaters

\section{References}

1. Srinivasan, S. Subsidy policy and enlargement of choice. Renew. Sustain. Energy Rev. 2009, 13, $2728-2733$. [CrossRef]

2. Mauthner, F.; Weiss, W. Solar Heat Worldwide; AEE-Institute for Sustainable Technologies: Gleisdorf, Austria, 2019.

3. Lin, W.M.; Chang, K.C.; Liu, Y.M.; Chung, K.M. Field surveys of non-residential solar water heating systems in Taiwan. Energies 2012, 5, 258-269. [CrossRef]

4. Liu, Y.M.; Chung, K.M.; Chang, K.C.; Lee, T.S. Performance of thermosyphon solar water heaters in series. Energies 2012, 5, 3266-3278. [CrossRef]

5. Hazami, M.; Kooli, S.; Naili, N.; Farhat, A. Long-term performances prediction of an evacuated tube solar water heating system used for single-family households under typical Nord-African climate (Tunisia). Sol. Energy 2013, 94, 283-298. [CrossRef]

6. Islam, M.R.; Sumathy, K.; Khan, S.U. Solar water heating systems and their market trends. Renew. Sustain. Energy Rev. 2013, 17, 1-25. [CrossRef]

7. Shukla, R.; Sumathy, K.; Erickson, P.; Gong, J. Recent advances in the solar water heating systems: A review. Renew. Sustain. Energy Rev. 2013, 19, 173-190. [CrossRef]

8. Karagiorgas, M.; Botzios, A.; Tsoutsos, T. Industrial solar thermal applications in Greece economic evaluation, quality requirements and case studies. Renew. Sustain. Energy Rev. 2001, 5, 157-173. [CrossRef]

9. Lauterbach, C.; Schmitt, B.; Jordan, U.; Vajen, K. The potential of solar heat for industrial processes in Germany. Renew. Sustain. Energy Rev. 2012, 16, 5121-5130. [CrossRef]

10. Powell, K.M.; Rashid, K.; Ellingwood, K.; Tuttle, J.; Iverson, B.D. Hybrid concentrated solar thermal power systems: A review. Renew. Sustain. Energy Rev. 2017, 80, 215-237. [CrossRef]

11. Ellingwood, K.; Safdarnejad, S.M.; Rashid, K.; Powell, K. Leveraging energy storage in a solar-tower and combined cycle hybrid power plant. Energies 2019, 12, 40. [CrossRef] 
12. Rashid, K.; Safdarnejad, S.M.; Safdarnejad, S.M.; Powell, K. Techno-economic evaluation of different hybridization schemes for a solar thermal/gas power plant. Energy 2019, 181, 91-106. [CrossRef]

13. Kalogirou, S.A. The energy subsidization policies of Cyprus and their effect on renewable energy systems economics. Renew. Energy 2003, 28, 1711-1728. [CrossRef]

14. Stevanovic, S.; Pucar, M. Financial measures Serbia should offer for solar water heating systems. Energy Build. 2012, 54, 519-526. [CrossRef]

15. Timilsina, G.R.; Lado Kurdgelashvilib, L.; Narbel, P.A. Solar energy: Markets, economics and policies. Renew. Sustain. Energy Rev. 2012, 16, 449-465. [CrossRef]

16. Pablo-Romero, M.P.; Sanchez-Braza, A.; Perez, M. Incentives to promote solar thermal energy in Spain. Renew. Sustain. Energy Rev. 2013, 22, 198-208. [CrossRef]

17. Abu-Baker, S.T.; Muhammad-Sukki, F.; Ramirez-Iniguez, R.; Munir, A.B.; Yasin, S.H.M.; Mallick, T.K.; McLennan, C.; Rahim, R.A. Financial analysis of the proposed renewable heat incentive for residential houses in the United Kingdom: A case on the solar thermal system. Energy Policy 2014, 65, 552-561. [CrossRef]

18. Aste, N.; Del Pero, C.; Adhikari, R.S.; Marenzi, G. Effectiveness and weaknesses of supporting policies for solar thermal systems-A case-study. Sustain. Cities Soc. 2015, 14, 146-153. [CrossRef]

19. Roulleau, T.; Lloyd, C.R. International policy issues regarding solar water heating, with a focus on New Zealand. Energy Policy 2008, 36, 1843-1857. [CrossRef]

20. Bureau of Energy, Ministry of Economic Affairs (BEMOEA). 2018 Energy Statistical Data Book; Bureau of Energy, Ministry of Economic Affairs: Taipei, Taiwan, 2019.

21. Chang, K.C.; Lin, W.M.; Chung, K.M. A lesson learned from the long-term subsidy program for solar water heaters in Taiwan. Sustain. Cities Soc. 2018, 41, 810-815. [CrossRef]

22. Pan, T.C.; Kao, J.J.; Wong, C.P. Effective solar radiation based on benefit and cost analysis for solar water heater development in Taiwan. Renew. Sustain. Energy Rev. 2012, 16, 1874-1882. [CrossRef]

23. Chang, K.C.; Lee, T.S.; Lin, W.M.; Chung, K.M. Outlook for solar water heaters in Taiwan. Energy Policy 2008, 36, 66-72. [CrossRef]

24. Chang, K.C.; Lin, W.M.; Lee, T.S.; Chung, K.M. Local market of solar water heaters in Taiwan: Review and perspectives. Renew. Sustain. Energy Rev. 2009, 13, 2605-2612. [CrossRef]

25. Chung, K.M.; Chang, K.C.; Chou, C.C. Wind load on residential and large-scale solar collector models. J. Wind Eng. Ind. Aerodyn. 2011, 99, 59-64. [CrossRef]

26. Chung, K.M.; Chou, C.C.; Chang, K.C.; Chen, Y.J. Wind loads on a residential solar water heater. J. Chin. Inst. Eng. 2013, 36, 870-877. [CrossRef]

27. Chou, C.C.; Chung, P.H.; Yang, R.Y. Wind loads on a solar panel at high tilt angles. Appl. Sci. 2019, 9, 1594. [CrossRef]

28. Chung, P.H.; Chou, C.C.; Chung, C.Y.; Yang, R.Y. Wind loads on a PV array. Appl. Sci. 2019, 9, 2466. [CrossRef]

29. Directorate General of Budget Accounting and Statistics (DGBAS). 2010 Population and Housing Census. Available online: https://census.dgbas.gov.tw/PHC2010/chinese/rchome.htm (accessed on 1 August 2019).

30. Chang, K.C.; Lin, W.M.; Lee, T.S.; Chung, K.M. Subsidy programs on diffusion of solar water heaters: Taiwan's experience. Energy Policy 2011, 39, 563-567. [CrossRef]

31. Lin, W.M.; Chang, K.C.; Chung, K.M. Economic aspects for solar thermal application in Taiwan. Sustain. Cities Soc. 2016, 26, 354-363. [CrossRef]

32. Wierling, A.; Schwanitz, P.; Zei, J.P.; Bout, C.; Candelise, C.; Winston Gilcrease, W.; Gregg, J.S. Statistical evidence on the role of energy cooperatives for the energy transition in European countries. Sustainability 2018, 10, 3339. [CrossRef]

33. Lin, W.M.; Fan, K.C.; Chang, K.C.; Chung, K.M. Dissemination of solar water heaters in Taiwan: The case of remote islands. Energies 2013, 6, 5101-5113. [CrossRef]

(C) 2019 by the authors. Licensee MDPI, Basel, Switzerland. This article is an open access article distributed under the terms and conditions of the Creative Commons Attribution (CC BY) license (http://creativecommons.org/licenses/by/4.0/). 